\title{
Genetic Characterization of Infectious Bursal Disease Viruses Associated with Gumboro Outbreaks in Chicken Flocks from El-Sharkia Province, Egypt.
}

\author{
Hashish, A.A. ${ }^{2}$, Abdullah A. Selim ${ }^{2}$, Mohamed F. Mandour ${ }^{1}$, \\ Mohamed M. Abd-Eldaim ${ }^{1}$, Shahira A. M. Abdelwahab ${ }^{1}$, El_Tarabili, \\ M. $\mathbf{M}^{1}$. \\ ${ }^{1}$ Virology Department, Faculty of Veterinary Medicine, Suez Canal \\ University, Ismailia, Egypt \\ ${ }^{2}$ National Laboratory for Veterinary Quality Control on Poultry Production, \\ Animal Health Research Institute
}

\begin{abstract}
Re-emergence of very virulent forms of IBDV has been the cause of significant economic losses in poultry industry in Egypt. In present study, 15 bursal samples were collected from flocks showing typical clinical signs and post mortem lesions of IBDV outbreaks. These bursal samples were tested using reverse transcriptase-polymerase chain reaction (RT-PCR) targeting VP2 gene of IBDV. Out of the tested samples $10(66.67 \%)$ were positives. Sequence analysis of PCR products of 4 selected samples according to strength of the bands on gel electrophoresis was carried out. All of the sequenced samples were characterized as very virulent (vvIBDV). The deduced amino acid sequence revealed that the four samples (Sharkia1,2,3,4) have amino acid sequence identity between each other (99.3 -100\%) and between Egyptian vvIBDV (Giza 2008, Giza 2000) strains (98.6 $-100 \%$ ). Genotyping of the four Egyptian vvIBDVs indicated that they were closely related to previous isolated strains from Egypt. So we aimed to find the homology between these collected IBDV samples and other field and vaccinal strains sequences.
\end{abstract}

\section{Introduction}

Infectious bursal disease (IBD) is an acute, highly contagious viral disease of chickens that characterized by degenerative lesions in the bursa of Fabricious result in fatal conditions and immune-suppression (Eterradossi and Saif, 2008). Infectious bursal disease virus (IBDV) is a nonenveloped virus belongs to the family Birnaviridae. IBDV has two serotypes; Serotype 1 IBDV strains (Van den berg et al, 2004), and serotype 2 strains (Mcferran et al, 1980). Serotype 1 viruses can be further categorized into 4 groups on 
the basis of their pathogenicity: Classical strains, variants, attenuated strains and very virulent strains (Lim et al, 1999). vvIBDV strains were reported to break through high levels of maternal antibodies, lead to lesions typical of IBDV and $100 \%$ mortality rates in susceptible chickens (Xiumiao et al, 2012). IBDV genome is divided into segments $\mathrm{A}(3.4 \mathrm{~kb})$ and $\mathrm{B}(2.7$ $\mathrm{kb})$. The larger segment A encodes 4 viral proteins, the two capsid proteins VP2 (48 $\mathrm{kDa})$ and VP3 $(32-35 \mathrm{kDa})$, the viral protease VP4 $(24 \mathrm{kDa})$, and a non-structural protein VP5 (17-21 kDa). The smaller segment B encodes VP1 (90 $\mathrm{kDa}$ ), an RNA-dependent RNA polymerase (Jackwood et al, 2008).

Amino acid position from 206 to 350 called hyper variable region (HVR) on VP2 were shown to represent a major neutralizing antigenic domain by expression/deletion studies (Van den Berg, 2000, that includes the most variable region that is important for pathogenic variation. Despite of chicken flocks are vaccinated against IBD, severe outbreaks of IBD were reported in chicken flocks in Egypt, caused high mortalities, and have become a serious problem (Bekhit, 1998; Metwally et al, 2009). To increase our understanding of the molecular epidemiology of IBDV in ElSharkia province, Egypt, the amino acid sequences of HVR of VP2 from Position 201 to 338 of 4 IBVs were analyzed and compared with other reference classical, variant and very virulent viral isolates from Egypt.

\section{Material and Methods}

1. Clinical signs and post mortem findings of chickens infected with IBDV:

Chickens from the affected flocks showed decrease feed intake, watery greenish diarrhea, ruffled feathers. Post mortem examination revealed that the affected chickens had enlarged hemorrhagic bursa, petical hemorrhage on thigh muscle and breast muscle and dehydrated carcass with degenerative changes in the kidney.

2. Sample collection

A total of 15 bursal tissues were collected from different chicken flocks showing typical clinical signs and gross lesions of IBD from different regions of El-Sharkia Province. The Chickens were vaccinated with a live attenuated IBDV vaccine (Bursavac ${ }^{\circledR}$ ) at day 11 and 22. The specimens were kept frozen at $-80^{\circ} \mathrm{C}$ until processing.

3. IBDV detection by RT-PCR

IBDV RNAs were extracted from the Bursal homogenates [one part of each bursa sample disrupting in sterile saline (1:1)] using QiAmp Viral RNA Mini kit (Qiagen GmbH, Hilden, Germany) according to the manufacturer's instructions. A set of primers were used for the RT-PCR reaction and for the subsequent sequence analysis using forward and reverse 
PCR primers for amplification of a $620 \mathrm{bp}$ fragment within IBDV on VP2: Forward primer (F): [AUS GU: 50-TCA CCG TCC TCA GCT TAC CCA CAT C-3].Reverse primer (R): [AUS GL: 50-GGA TTT GGG ATC AGC TCG AAG TTG C-3] (Metwally et al., 2009).

Briefly, the $50 \mu 1$ reaction mixture contained $10 \mu \mathrm{l}$ of $5 \times \mathrm{RT}$-PCR buffer, $2 \mu 1$ primer $\mathrm{F}, 2 \mu 1$ primer $\mathrm{R}$, $2 \mu \mathrm{l}$ dNTP mix containing $400 \mu \mathrm{M}$ each dATP, dGTP, dCTP, dTTP, 2 $\mu 1$ of Qiagen One Step Enzyme Mix and $10 \mu \mathrm{l}$ of extracted RNA. A fragment of $620 \mathrm{bp}$ was amplified by PCR thermo cycling using (T3 Biometra-Germany) as follows: 20 min at $50{ }^{\circ} \mathrm{C}$ (RT reaction); $95{ }^{\circ} \mathrm{C}$ for $15 \mathrm{~min}$ (initial PCR activation); 40 three-step cycles of $94{ }^{\circ} \mathrm{C}$ for 30 $\mathrm{s}$ (denaturation), $59{ }^{\circ} \mathrm{C}$ for $40 \mathrm{~s}$ (annealing) and $72{ }^{\circ} \mathrm{C}$ for $1 \mathrm{~min}$; then $72{ }^{\circ} \mathrm{C}$ for $10 \mathrm{~min}$ (final extension). After amplification, 13 $\mu 1$ of PCR products were analyzed by electrophoresis on a $1.5 \%$ agarose gel containing ethidium bromide with final concentration of $0.5 \mu \mathrm{g} / \mathrm{ml}$ at $95 \mathrm{~V}$ for $30 \mathrm{~min}$ in $1 \times$ TBE buffer, against GeneRuler TM 100 bp Plus DNA Ladder (Fermentas). Images of the gels were photographed on BioDoc Analyze Digital Systems (Biometra, Germany) (Metwally et al., 2009).

4. Sequence analysis of VP2 of IBDV

Gel containing DNA band of the expected size (620 bp) was excised and purified with the QIAquick Gel Extraction Kit (Qiagen) according to the manufacturer instruction. The purified PCR products were sequenced directly using the $\mathrm{ABI}$ PRISM BigDyeTM Terminators v3.1 Cycle Sequencing Kit (Applied Biosystems, Foster City, CA, USA) and the ABI PRISM 3130 genetic analyzer (Applied Biosystems) with $80 \mathrm{~cm}$ capillaries. The sequences were edited with SeqScape Software Version 2.5 (Applied Biosystems), alignment trimming was performed With Bioedit software. The phylogram was drawn using also MEGA 5 software with a bootstrap resampling method (1000 bootstraps). Egyptian viruses and other international reference strains from the Genbank were available from the National Center for Biotechnology Information (NCBI) infectious bursal disease viruses resource (http://www.ncbi). The identity percent and divergence between all viruses was carried out using MegAlign software.

\section{Results}

1. Identification of Virus Using RTPCR

Out of 15 bursal samples tested with RT-PCR, 10 samples

(66.7\%) were positive. All RT-PCR positive samples showed specific bands at $620 \mathrm{bp}$ on agarose gel $(1.5 \%)$ as expected (Figure 1).

2. Sequence analysis and phylogenetic tree of IBDV:

Sequence analysis of the 414 nucleotides which express 138 amino acid sequences (Position 201 
to 338) from the four selected samples were carried out.

The deduced amino acid sequence revealed that the four samples (Sharkia1,2,3,4) have amino acid sequence identity between each other $(99.3-100 \%)$ and between Egyptian vvIBDV (Giza 2000, Giza 2008) strains (98.6 - 100\%). As shown in Table (1)

Phylogenetic tree (Figure 2) indicated that the four IBDV in this study showed close relationships with previously isolated Egyptian IBDVs (Giza 2000 and Giza 2008) and they are clustered together.

Sequence analysis of the four IBDV samples revealed the highly virulent nature of those viruses. It was found that none of the examined samples were of attenuated or vaccinal origin due to absence of 253Histidine and 284-Threonine substitutions that typically found in attenuated vaccine strains. Figure (3).

All of the examined isolates showed the characteristics of vvIBDV amino acid substitutions at residues 222 (A), 242 (I), 253 (Q), 256 (I), 279 (D), 284 (A), 299 (S) and 330 (S). Also the serine-rich heptapeptide SWSASGS that found next to the second hydrophilic region 326-332 was confirmed in all examined samples.

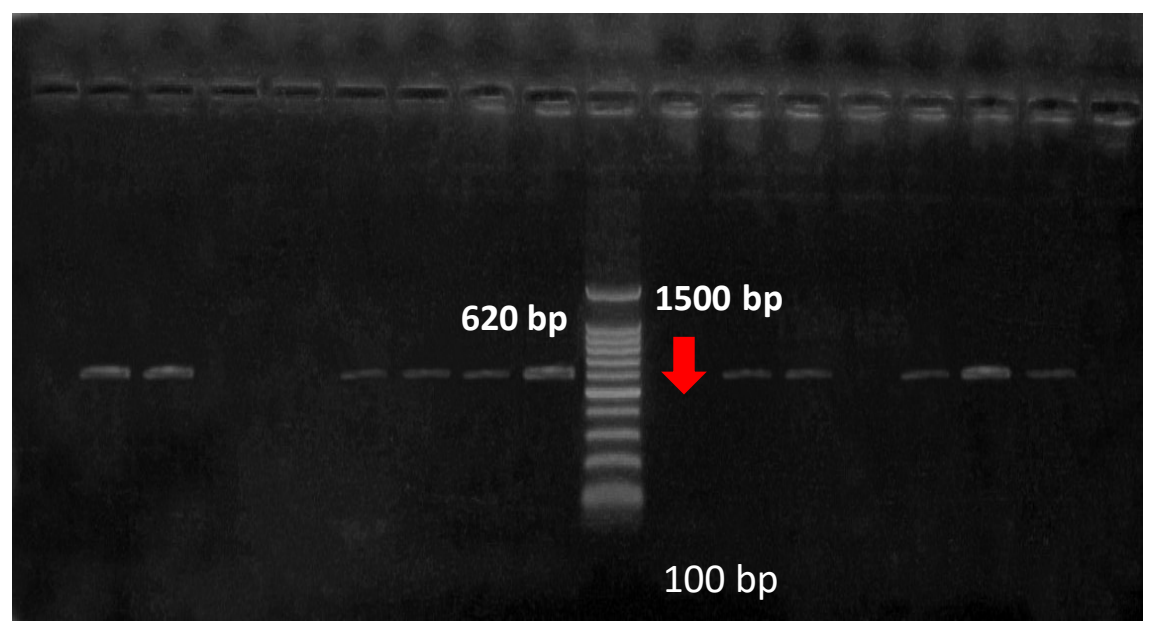

Figure 1: showed RT-PCR results of 15 examined samples, $M: 100 \mathrm{bp}$ marker, NC: negative control, PC: positive control, Lane 1,2,3,5,6,8,9,10,13\&14 positive samples, Lane 4,7,11,12\&15 negative samples. 
Table 1: amino acid similarity (\%) of the four sequenced IBDV samples with reference classical, very virulent, variant and vaccinal IBDV strains

\begin{tabular}{|c|c|c|c|c|c|c|c|c|c|c|c|c|c|c|c|c|c|c|c|c|}
\hline \multicolumn{21}{|c|}{ Percent Identity } \\
\hline & 1 & 2 & 3 & 4 & 5 & 6 & 7 & 8 & 9 & 10 & 11 & 12 & 13 & 14 & 15 & 16 & 17 & 18 & & \\
\hline 1 & & 92.0 & 93.5 & 90.6 & 91.3 & 92.8 & 92.8 & 92.8 & 92.8 & 94.9 & 95.7 & 95.7 & 92.0 & 98.6 & 91.3 & 91.3 & 90.6 & 91.3 & 1 & kal2001 \\
\hline 2 & 8.4 & & 97.8 & 90.6 & 91.3 & 91.3 & 91.3 & 91.3 & 91.3 & 91.3 & 92.0 & 92.0 & 89.9 & 92.0 & 91.3 & 91.3 & 90.6 & 91.3 & 2 & variant \\
\hline 3 & 6.8 & 2.2 & & 92.0 & 92.8 & 92.8 & 92.8 & 92.8 & 92.8 & 92.8 & 93.5 & 93.5 & 91.3 & 93.5 & 92.8 & 92.8 & 92.0 & 92.8 & 3 & variant \\
\hline 4 & 10.1 & 10.1 & 8.4 & & 99.3 & 97.8 & 97.8 & 97.8 & 97.8 & 91.3 & 93.5 & 92.0 & 89.9 & 90.6 & 99.3 & 99.3 & 98.6 & 99.3 & 4 & Giza \\
\hline 5 & 9.3 & 9.3 & 7.6 & 0.7 & & 98.6 & 98.6 & 98.6 & 98.6 & 92.0 & 94.2 & 92.8 & 90.6 & 91.3 & 100.0 & 100.0 & 99.3 & 100.0 & 5 & Giza \\
\hline 6 & 7.6 & 9.3 & 7.6 & 2.2 & 1.5 & & 100.0 & 100.0 & 100.0 & 93.5 & 95.7 & 94.2 & 92.0 & 92.8 & 98.6 & 98.6 & 97.8 & 98.6 & 6 & k357-88 \\
\hline 7 & 7.6 & 9.3 & 7.6 & 2.2 & 1.5 & 0.0 & & 100.0 & 100.0 & 93.5 & 95.7 & 94.2 & 92.0 & 92.8 & 98.6 & 98.6 & 97.8 & 98.6 & 7 & NIE \\
\hline 8 & 7.6 & 9.3 & 7.6 & 2.2 & 1.5 & 0.0 & 0.0 & & 100.0 & 93.5 & 95.7 & 94.2 & 92.0 & 92.8 & 98.6 & 98.6 & 97.8 & 98.6 & 8 & D6948 \\
\hline 9 & 7.6 & 9.3 & 7.6 & 2.2 & 1.5 & 0.0 & 0.0 & 0.0 & & 93.5 & 95.7 & 94.2 & 92.0 & 92.8 & 98.6 & 98.6 & 97.8 & 98.6 & 9 & KS \\
\hline 10 & 5.3 & 9.3 & 7.6 & 9.3 & 8.4 & 6.8 & 6.8 & 6.8 & 6.8 & & 96.4 & 99.3 & 91.3 & 93.5 & 92.0 & 92.0 & 91.3 & 92.0 & 10 & BursaVac \\
\hline 11 & 4.5 & 8.4 & 6.8 & 6.8 & 6.0 & 4.5 & 4.5 & 4.5 & 4.5 & 3.7 & & 97.1 & 92.0 & 94.2 & 94.2 & 94.2 & 93.5 & 94.2 & 11 & CEVAC \\
\hline 12 & 4.5 & 8.4 & 6.8 & 8.4 & 7.6 & 6.0 & 6.0 & 6.0 & 6.0 & 0.7 & 3.0 & & 92.0 & 94.2 & 92.8 & 92.8 & 92.0 & 92.8 & 12 & Univax \\
\hline 13 & 8.4 & 10.9 & 9.3 & 10.9 & 10.1 & 8.4 & 8.4 & 8.4 & 8.4 & 9.3 & 8.4 & 8.4 & & 90.6 & 90.6 & 90.6 & 89.9 & 90.6 & 13 & Bursine \\
\hline 14 & 1.5 & 8.4 & 6.8 & 10.1 & 9.3 & 7.6 & 7.6 & 7.6 & 7.6 & 6.8 & 6.0 & 6.0 & 10.1 & & 91.3 & 91.3 & 90.6 & \begin{tabular}{|l|}
91.3 \\
\end{tabular} & 14 & D78 \\
\hline 15 & 9.3 & 9.3 & 7.6 & 0.7 & 0.0 & 1.5 & 1.5 & 1.5 & 1.5 & 8.4 & 6.0 & 7.6 & 10.1 & 9.3 & & 100.0 & 99.3 & 100.0 & 15 & Sharkia \\
\hline 16 & 9.3 & 9.3 & 7.6 & 0.7 & 0.0 & 1.5 & 1.5 & 1.5 & 1.5 & 8.4 & 6.0 & 7.6 & 10.1 & 9.3 & 0.0 & & 99.3 & 100.0 & 16 & Sharkia \\
\hline 17 & 10.1 & 10.1 & 8.4 & 1.5 & 0.7 & 2.2 & 2.2 & 2.2 & 2.2 & 9.3 & 6.8 & 8.4 & 10.9 & 10.1 & 0.7 & 0.7 & & 99.3 & 17 & Sharkia \\
\hline 18 & 9.3 & 9.3 & 7.6 & 0.7 & 0.0 & 1.5 & 1.5 & 1.5 & 1.5 & 8.4 & 6.0 & 7.6 & 10.1 & 9.3 & 0.0 & 0.0 & 0.7 & & 18 & Sharkia \\
\hline & 1 & 2 & 3 & 4 & 5 & 6 & 7 & 8 & 9 & 10 & 11 & 12 & 13 & 14 & 15 & 16 & 17 & 18 & & \\
\hline
\end{tabular}

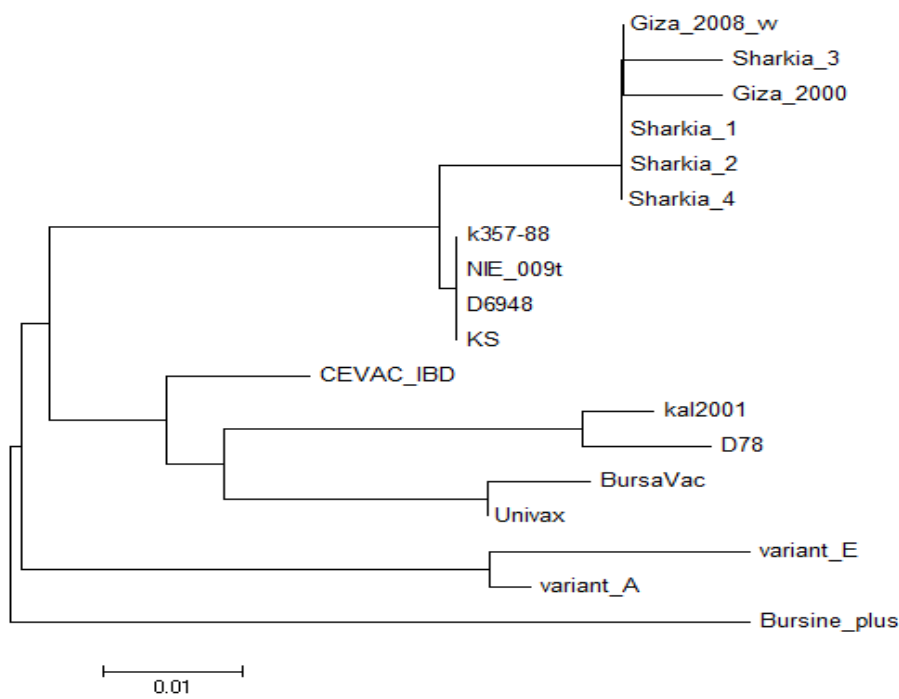

Figure 2: Phylogenetic tree of deduced amino acids sequences of the four $I B D V$ samples and other reference classical, very virulent, variant and vaccinal strains of IBDV.

kal2001

variant $\mathbf{E}$

variant $A$

Giza 2000

Giza 2008 vv

k357-88

NIE 009t

D6948
204

214

224

234

244

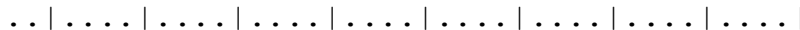

DRPRVYTITAADDYQFSSQYQPGGVTITLFSANIDAITSLSVGG

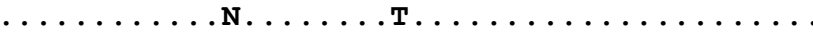

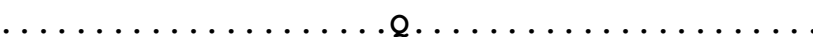

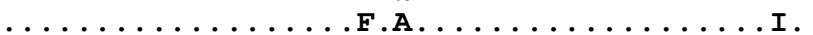

$\ldots \ldots \ldots \ldots \ldots$. $\ldots \ldots \ldots$. .

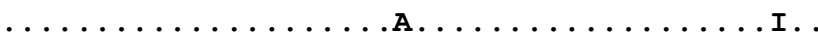

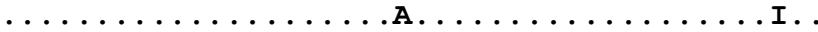

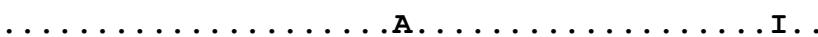


KS

Bursavac

CEVAC IBD

Univax

Bursine plus

D78

Sharkial

Sharkia2

Sharkia3

Sharkia4

304

kal2001

variant $\mathbf{E}$

variant $A$

Giza 2000

Giza 2008 vv

k357-88

NIE $009 t$

D6948

KS

Bursavac

CEVAC IBD

Univax

Bursine plus

D78

Sharkial

Sharkia2

Sharkia3

Sharkia4

kal2001

variant $\mathbf{E}$

variant $A$

Giza 2000

Giza 2008 vv

k357-88

NIE 009t

D6948

KS

Bursavac

CEVAC IBD

Univax

Bursine plus

D78

Sharkial

Sharkia2

Sharkia3

Sharkia4

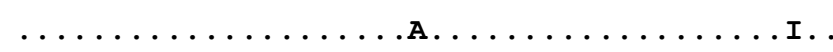

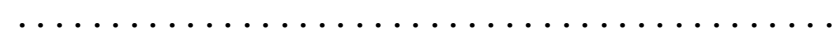
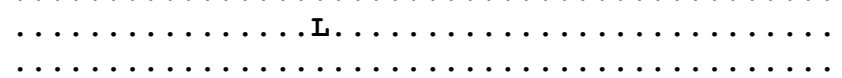

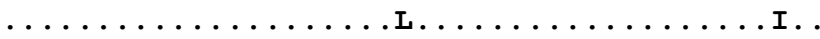

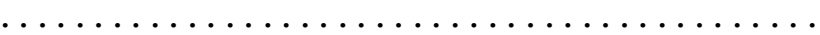

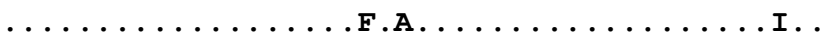

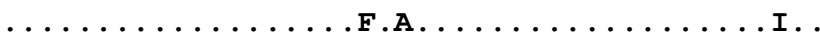

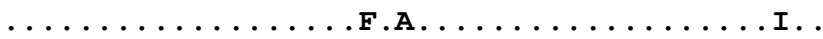

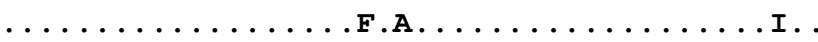

$\begin{array}{lllll}254 & 264 & 274 & 284 & 294\end{array}$

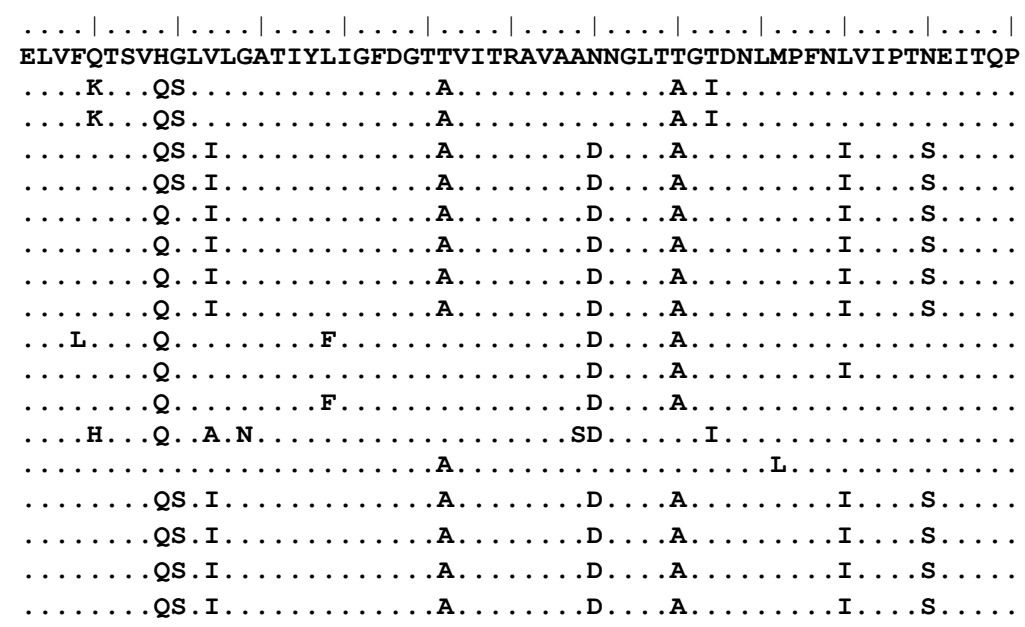

314

324

334

ITSIKLEIVTSKSGGQAGDQMSWSARGSLAVTIH

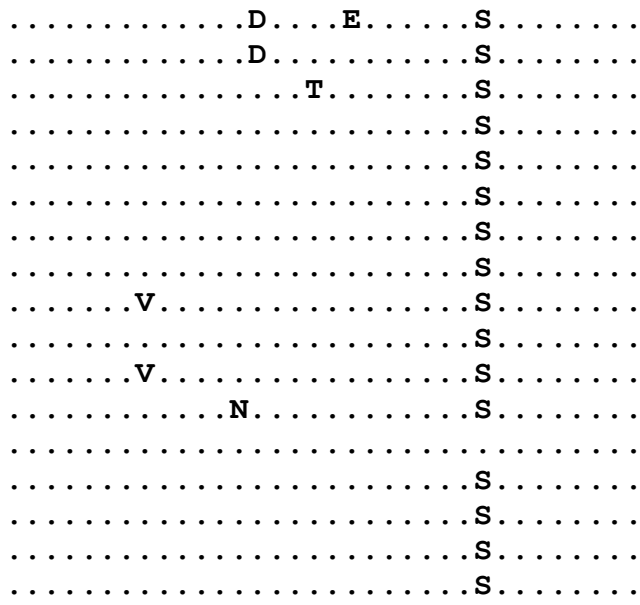

Figure 3: Alignment of deduced amino acid sequence of the VP2 variable domain from a a positions 201 to 338 (numbering according to Bayliss et al (1990) of the four selected samples. 


\section{Discussion}

Infectious bursal disease virus continuous to be a serious threat in Egypt as it does in other poultry producing countries worldwide. A preventive program is necessary to avoid virus spread and disease appearance (Hussein et al, 2003). The clinical diagnosis of the acute form of IBD depends on the observation of the symptoms and gross lesions examination. Clinical signs depend on the virulence of the virus, age of bird and immune status of the bird (Rauw et al, 2007).

Observed clinical signs in this study were anorexia, watery diarrhea, ruffled feathers and general weakness. Post mortem examination revealed that the affected chickens had enlarged hemorrhagic bursa, poetical hemorrhage on thigh and breast muscle in addition to dehydrated carcass. These clinical signs and gross lesions observed in the affected birds were all suggestive of IBD. More or less similar types of signs and/or gross lesions have been recorded earlier by various researchers (El-Khayat, 2003; Sara et al, 2014). All these symptoms may be attributed to the harmful effect of the virus on the kidney.

The definite identification of IBDV was obtained using RT-PCR which was known to be a sensitive test to detect the IBDV (Abdel-Alem et al, 2003). In this study 10 out of 15 field samples were positive by RT-
PCR. Similar results were obtained by Moemen et al (2014).

In this study amino acid sequencing, comparative alignment, and phylogenetic analysis of the (hVP2) was done for selected four field samples.

The deduced amino acid sequences for each tested IBDV samples from position (201 to 338) numbering according to (Bayliss et al., 1990) were analyzed.

The virulence marker aa residues 222(A), 242(I), 253(Q), 256(I), 279(D), 284(A), 299(S), 330(S) and 451 (L) are conserved in the VP2 of vvIBDVs (Van Den Berg et al., 2004).

In our study all of the examined samples had 8 of the virulence marker aa residues (except $451 \mathrm{~L}$ not involved in the sequenced fragment in this study). The presence of these aa residues in the four samples proved the very virulence nature of these samples.

The hydrophilic regions A (from aa 212 to 224), B (from aa 312 to 324 ), 1 (from aa 248 to 254) and 2 (from aa 279 to 290 ) have been shown to be important in the binding of neutralizing monoclonal antibodies and are presumed to be the dominant parts of the neutralizing domain (Schnitzler et al, 1993).

Sequencing results in this study revealed changes in amino acid substitutions at major hydrophilic peak $A$ at position (220 and 222). 
Substitution occur at position 220 revealed that the four examined samples had F220 that was similar to VV strain Giza 2000 and Giza 2008.

Presence of Alanine (A) at position 222 instead of Proline (P) in the four sequenced samples was similar to very virulent Giza 2008. Amino acid residue at the position 222 is very critical as various publications reported a change in the aa residue at position 222 in some vvIBDV strains ( $\mathrm{P}$ to $\mathrm{A}$ ) and in some variant strains such as variant A (P to Q) (Heine et al, 1991). Similar results were predicted by Brown et al (1994).

In minor hydrophilic peak 1, regarding to aa residue at position 253 (Q) our results agreed with Islam et al (2012) who reported that presence of Glutamine (Q) residue at position 253 was found in the two isolates examined in his study as well as the previously isolated Bangladeshi IBDV. This residue thought to be responsible for pathogenicity and is unique to highly virulent IBDV. This result also supported by Negash et al (2012) who reported Glutamine (Q) at position 253 .

Other amino acid substitution occur at position 254, that four examined samples had Serine (S) at position 254 that agreed with Negash et al (2012) who reported that all Ethiopian strains have amino acid residues characteristic of variant strains at the minor hydrophilic peak 1 position (254S). Exchanges of amino acid in this position may likely result in antigenic changes (Durairaj et al, 2011), and lead to a modified structure of the neutralizing epitopes (Martin et al, 2007), which was verified recently in an in vivo study (Jackwood and Sommer Wanger, 2011).

These results agreed with Brandt et al (2001) who reported that reverse genetic experiments have shown that the amino acid at position 253 in VP2 affects the virulence of IBDV.

In minor hydrophilic peak 2, other aa substitution at position 279 and 284 were shown. Four examined samples had Aspartic acid (D) at position 279 and Alanine (A) at position 284 that were similar to vvIBDV Giza 2000 and Giza 2008. This is in agreement with Islam et al (2012) who reported that presence of Alanine (A) at position 284 was found in the two isolates examined in his study.

Hernandez et al (2006) noticed that four amino acid residues have been conserved in most vvIBDV strains (222A, 256I, 294I and 299S) and were detected in all Uruguayan sequences. All of these amino acid residues were detected in the four examined samples

The serine rich heptapeptide SWSASGS (326-332) located immediately downstream of the second hydrophilic region was believed to be involved in the virulence of IBDV (Heine et al, 1991). At this study presence of typical heptapeptide (SWSASGS) 
in the four examined samples indicating that they were pathogenic strains. This was in agreement with Heine et al (1991) and Razmayr and peighambari (2008).

These results indicate that our strains are highly related to vvIBDV strains belonging to serotype 1 isolates and also indicating that they are pathogenic strains and that vvIBDV belong to Egyptian strains succeeded in surviving in the Egyptian environment despite the intensive use of vaccination programs. This observation had the support of Eterradossi et al (2004).

\section{References}

Abdel-Alem GA, Awaad MH, and Saif YM (2003): Characterization of Egyptian field strains of infectious bursal disease virus. Avian Dis; 47:1452-1457.

Azad AA, Jagadish MN, Brown MA and Hudson PJ (1987): Deletion mapping and expression in Escherichia coli of the large genomic segment of a birnavirus. Virol. 161: 145-152.

Bayliss C, Spies U, Shaw K, Peters R, Papageorgiou A, Muller $H$, and Boursnell $M$ (1990): A comparison of the sequences of segment A of four infectious bursal disease virus strains and identification of a variable region in VP2. J. Gen. Virol. 71 (6): 1303 1312.

Bekhit AB (1998): "Acute infectious bursal disease in poultry, isolation of very virulent strains,"
Alexandria Journal of Veterinary Sciences, 11: 475-483.

Brandt M, Yao K, Liu M, Heckert $R$, and Vakharia $V$ (2001): Molecular determinants of virulence, cell tropism, and pathogenic phenotype of infectious bursal disease virus. J. Virol. 75: 11974-11982.

Brown M, Green P, and Skinner M (1994): VP2 sequences of recent European 'very virulent' isolates of infectious bursal disease virus are closely related to each other but are distinct from those of 'classical' strains. J. Gen. Virol. 75 (3): 675680.

Durairaj V, Sellers H, Linnemann E, Icard A, and Mundt E (2011): Investigation of the antigenic evolution of field isolates using the reverse genetics system of infectious bursal disease virus (IBDV). Arch. Virol. 156: 17171728.

El-Khayat FF (2003): Evaluation of some vaccination programs against infectious bursal disease (Gumboro) in Egypt Ph. D. thesis fac: Vet. Med. Kefir El-Sheikh Branch, Tanta Univ.

Eterradossi $\mathbf{N}$ and Saif $Y$ (2008): "Infectious bursal disease," in Diseases of Poultry, Saif Y, Fadly AM, Glisson JR, McDougald LR, Nolan LK, and Swayne DE, Eds., pp. 185-208,Wiley-Blackwell, Ames, Iowa, USA, 12th edition.

Eterradossi N, Gauthier C, Reda I, Comteand S, and Rivallan $G$ (2004): Extensive antigenic changes in an atypical isolate of very 
virulent infectious bursal disease virus and experimental clinical control of this virus with an antigenically classical live vaccine. Avian Pathol. 33: 423-431.

Heine H, Hsritou M, Faille P, Fahey K, and Azad A (1991): Sequence analysis and expression of host-protective immunogen VP2 of a variant strains of infectious bursal disease virus. Which can circumvent vaccination with standard type I strains. J. Gen. Virol. 72: 1835-1843.

Hernandez M, Banda A, Hernandez D, Panzera F, and Perez R (2006): Detection of very virulent strains of infectious bursal disease virus (vvIBDV) in commercial broiler from Uruguay. Avian dis. 50: 624-631.

Hussein A, Aly A, Sultan H, and Al-Safty M (2003): Transmissible viral pronventriculitis and stunting syndrome in broiler chicken in Egypt. 1. Isolation and characterized of variant infectious bursal disease virus. Vet Med J Giza; 51(3):445-462.

Islam MT, Hoa TT, Rahman MM, and Islam MA (2012): Molecular characterization of two Bangladeshi infectious bursal disease virus isolates using the hypervariable sequence of VP2 as a genetic marker. J. Vet. Sci.13 (4), 405-412.

Jackwood D and SommerWagner S (2011): Amino acids contribut into antigenic drift in the infectious bursal disease Birna virus (IBDV). Virol. 409: 33- 37.
Jackwood D, Sreedevi B, LeFever $\mathrm{L}$, and Sommer-Wagner S (2008): "Studies on naturally occurring infectious bursal disease viruses suggest that a single amino acid substitution at position 253 in VP2 increases pathogenicity," Virol. 377 (1): 110-116.

Lim BL, Cao Y, Yu T, and Mo CW (1999): Adaptation of very virulent infectious bursal disease virus to chicken embryonic fibroblasts by site-directed mutagenesis of residues 279 and 284 of viral coat protein VP2. J. Virol. 73: 2854-2862.

Martin A, Fallacara F, Barbieri I, Tosi G, Rivallan G, Eterradossi N, Ceruti R, and Cordioli P (2007): Genetic and antigenic characterization of infectious bursal disease viruses isolated in Italy during the period2002-2005. Avian Dis. 51: 863-872.

McFerran JB, McNulty MS, McKillop FR, Connor TJ, McCracken RM, Collins DS, and Allan GM (1980): Isolation and serological studies with infectious bursal disease viruses from fowl, turkeys and ducks - demonstration of a 2nd serotype. Avian Pathol. 9: 395-404.

Metwally AM, Yousif AA, Shaheed IB, Mohammed WA, Sami AM, and Reda M (2009): Re- Emergence of very virulent IBDV in Egypt .inter. J. Virol. 5 (1): 1-17.

Moemen AM, Kamal ES, Bakhit MB, and Marwa MS (2014): 
Genetic Characterization of Infectious Bursal Disease Viruses Associated with Gumboro Outbreaks in Commercial Broilers from Asyut Province, Egypt. Hindawi Publishing Corporation ISRN Veterinary Science Volume 2014, Article ID 916412, 9 pages.

Negash T, Gelaye E, Petersen $H$, Grummer B, and Rautenschlein $\mathrm{S}$ (2012): Molecular evidence of very virulent infectious bursal disease virus in chickens in Ethiopia. Avian Dis. 56: 605-610.

Rauw F, Lambrecht B, and Van den Berg $T$ (2007): Pivotal role in the pathogenesis of ChIFNgamma and immunosuppression of infectious bursal disease. Avian Pathol. 36(5): 367-374.

Razmyar J and Peighambari S (2008): Molecular characterization of Iranian infectious bursal disease viruses. Avian Dis. 52: 665-669.

Sara AM, Arafa AA, and Hussein AH (2014): Molecular genotyping of the infectious bursal disease virus (IBDV) isolated from Broiler
Flocks in Egypt. Int. J. Vet. Sci. Med. 2: 46-52.

Schnitzler D, Bernstein F, Muller $H$, and Becht $H$ (1993): The genetic basis for the antigenicity of the VP2 protein of the infectious bursal disease virus. J. Gen. Virol. 74 (8): 1563-1571.

Van den Berg TP (2000): Acute infectious bursal disease in poultry: a review. Avian Pathol. 29: 175194.

Van den Berg T, Morales D, Eterradossi N, Rivallan G, Toquin D, Raue R, Zierenberg K, Zhang M, Zhu Y, Wang C, Zheng H, Wang X, Chen G, Lim $B$, and Muller $H$ (2004): Assessment of genetic, antigenic and patho-type criteria for the characterization of IBDV strains. Avian Pathol. 33: 470-476.

Xiumiao H, Dingming G, Ping W, Xiuving $Y$, Guijun $W$, and Aijian Q (2012): "Molecular epidemiology of infectious bursal disease viruses isolated from Southern China during the years 2000-2010," Virus Genes, 45: 246-255. 


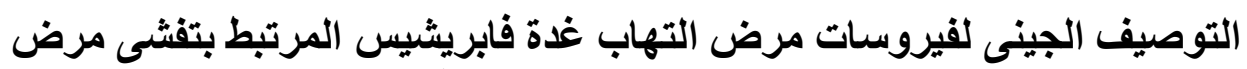

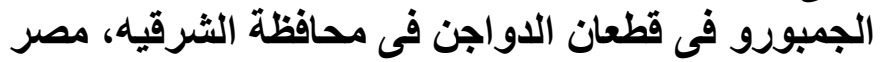

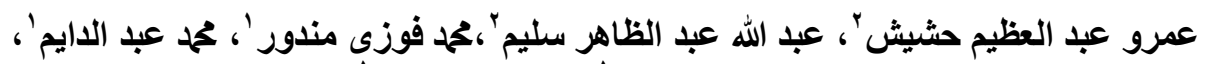

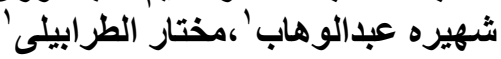

'قسم الفيروسات، كلية الطب البيطري، جامعة قناة السوبي، الاسماعيليه، جههورية مصر العربية

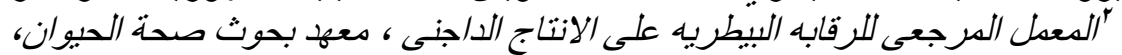
جمهوربية مصر العربية التية

اتخذ هذا العمل البحثى الحالى اهدافه فى التوصيف الجزيئى لعينات فيروس مرض اضن التهاب غدة

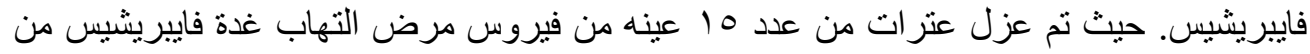

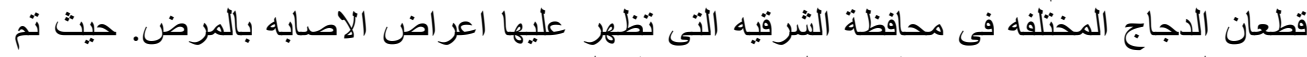

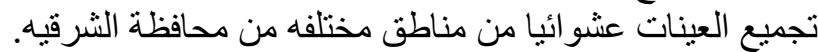

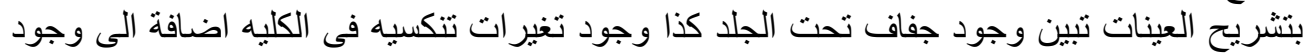

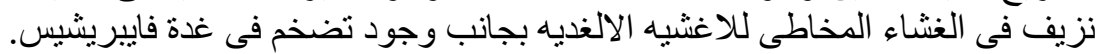

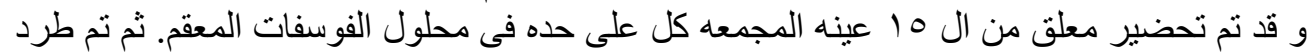

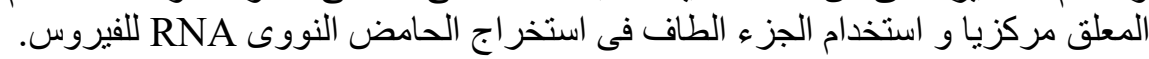

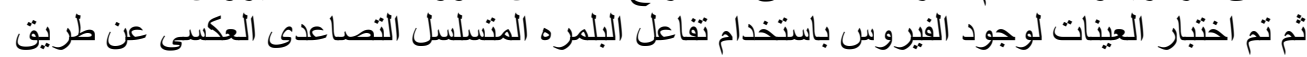

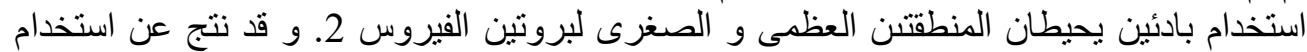

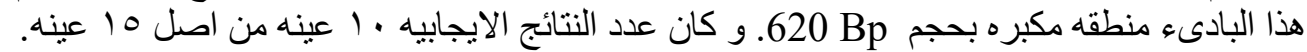

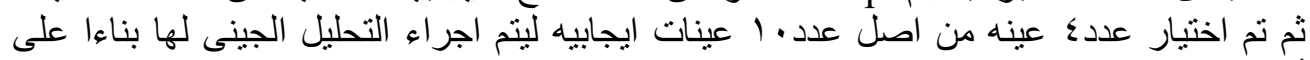
أعلى نتيجه ايجابيه. و قد اظهرت نتبه ائج التحليل الجينى ان كل العينات المختاره اظهرت نسبة تشابه عاليه للمعزول

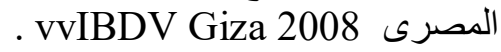

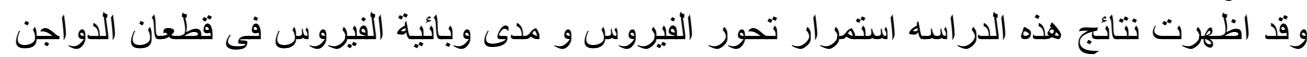

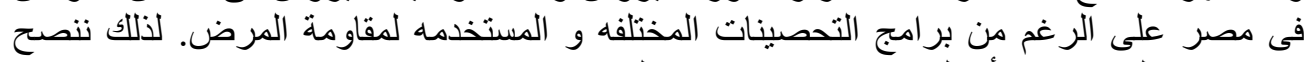

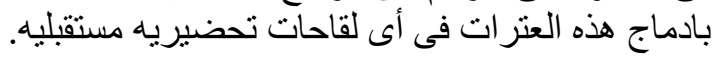

